\title{
The effect of radiological distribution on the COVID-19 disease
}

\author{
Mutlu \\ KULUÖZTÜRK ${ }^{\mathbf{1}}(\mathrm{ID})$ \\ Erdal iN ${ }^{1}(I D)$ \\ Teyfik TURGUT ${ }^{1}$ (ID) \\ Ayşe MURAT AYDIN² (ID) \\ Zülal AŞÇI \\ TORAMAN $^{3}$ (ID) \\ Figen DEVECi ${ }^{1}$ (ID)
}

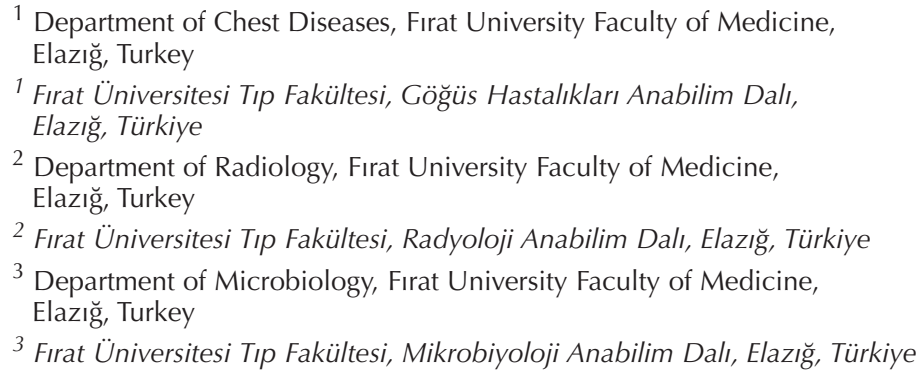

Cite this article as: Kuluöztürk $M$, in E, Turgut T, Murat Aydin A, Aşcı Toraman Z, Deveci F. The effect of radiological distribution on the COVID-19 disease. Tuberk Toraks 2021;69(2):187-195.

Yazışma Adresi (Address for Correspondence)

\section{Dr. Figen DEVECi}

Fırat Üniversitesi Tıp Fakültesi,

Göğüs Hastalıkları Anabilim Dalı,

ELAZIĞ - TÜRKIYE

e-mail: fgndeveci@yahoo.com

\footnotetext{
CCopyright 2021 by Tuberculosis and Thorax.
}

Available on-line at www.tuberktoraks.org.com

\section{ABSTRACT}

The effect of radiological distribution on the COVID-19 disease

Introduction: The aim of the study was to investigate the effects of radiological distribution on COVID-19 clinic and prognosis and to determine the relationship between laboratory parameters and thorax CT findings.

Materials and Methods: Patients with COVID-19 were evaluated retrospectively. Laboratory parameters were obtained from medical records. Groundglass opacities (GGO) and consolidation were evaluated on thorax CT. The presence of a single lobe lesion was considered as limited while multiple lobe lesions were considered as diffuse involvement for both GGO and consolidation.

Results: A total 200 patients with COVID-19 were evaluated. 178 of them (89\%) were discharged, 17 patients ( $8.5 \%)$ were transferred to the ICU and five patients died $(2.5 \%)$. The ratios of mortality and transfer to the ICU in patients with diffused GGO were significantly higher compared to patients with limited GGOs. It was observed that troponin $\geq 0.06 \mu \mathrm{g} / \mathrm{L}$, platelet $<140$ and fibrinogen $\geq 350 \mathrm{mg} / \mathrm{dl}$ were independent predictors of the presences of diffused GGOs in thorax CT.

Conclusion: Diffused GGOs on thorax CT are correlated with the rate of mortality and transfer to the ICU in patients with COVID-19. Also, troponin, fibrinogen, and platelet levels can be used while predicting extensive parenchymal disease on thorax CT.

Key words: COVID-19; thorax CT; troponin; fibrinogen; platelet levels 
ÖZ

\section{Radyolojik dağılımın COVID-19 hastalığına etkisi}

Giriş: Çalışmanın amacı radyolojik dağılımın COVID-19 kliniği ve prognozu üzerine etkilerini araştırmak ve laboratuvar parametreleri ile toraks BT bulguları arasındaki ilişkiyi belirlemektir.

Materyal ve Metod: COVID-19 hastaları retrospektif olarak değerlendirildi. Laboratuvar parametreleri tıbbi kayıtlardan elde edildi. Toraks BT'de buzlu cam opasiteleri (BCO) ve konsolidasyon değerlendirildi. Tek lobda lezyon varlığı sınırlı tutulum olarak kabul edilirken, çoklu lob lezyonları hem BCO hem de konsolidasyon için yaygın tutulum olarak kabul edildi.

Bulgular: COVID-19'lu toplam 200 hasta değerlendirildi. Olguların 178'i (\%89) taburcu edildi, 17 hasta (\%8,5) YBÜ'ye sevk edildi ve 5 hasta $(\% 2,5)$ öldü. Yaygın BCO olan hastalarda mortalite ve YBÜ'ye transfer oranları, sınırlı BCO olan hastalara kıyasla anlamlı derecede daha yüksekti. Troponin $\geq 0,06 \mu \mathrm{g} / \mathrm{L}$, trombosit $<140$ ve fibrinojenin $\geq 350 \mathrm{mg} / \mathrm{dl}$ olmasının toraks BT'de yaygın GGO varlığı için bağımsız risk faktörleri olduğu belirlendi.

Sonuç: Toraks BT'deki yaygın BCO varlığı COVID-19 hastalarında ölüm oranı ve YBÜ'ye transfer ile ilişkilidir. Ayrıca, troponin, fibrinojen ve trombosit seviyeleri toraks BT'de yaygın parankimal hastalı̆̆ını öngörmede kullanılabilir.

Anahtar kelimeler: COVID-19; toraks ct; troponin; fibrinojen; trombosit düzeyleri

\section{INTRODUCTION}

A rapid and accurate diagnosis in the COVID-19 pandemic is vital for the isolation and treatment of patients (1). Radiological imaging has played an important role in rapid and valid diagnosis in pandemic periods. Although postero-anterior (PA) chest radiography includes less radiation exposure and is practiced with portable equipment, computed tomography $(\mathrm{CT})$ of the thorax attracts attention due to its high sensitivity and specificity. In addition to the diagnostic importance of $\mathrm{CT}$ of the thorax, preliminary data has demonstrated that the extent of pulmonary parenchymal involvement id associated with the clinical severity of the disease and the need for intensive care in COVID-19 patients (2-4).

In our study, we aimed to investigate the effects of radiological distribution on COVID-19 clinic and prognosis in our patients. Additionally, we aimed to evaluate the correlation between laboratory parameters and thorax $\mathrm{CT}$ findings.

\section{MATERIALS and METHODS}

\section{The Population of the Study}

In the study, ethical approval was first obtained from the institutional review board at Firat University Ethical Committee (Approval No: 04/06/2020394781). Accordingly, the study was deemed appropriate by the board. Informed consent was not taken and analysis was performed with anonymous clinical data because of the retrospective design of our study.

Two hundred patients with COVID-19 infections, who were hospitalized in the pandemic clinic in the
Faculty of Medicine at Fırat University from March 2020 to September 2020, were included in the study retrospectively. COVID-19 infection was diagnosed according to the positive RT-PCR result and/or clinically and radiologically. PA chest radiographs and/or thorax CT of the patients with COVID-19 were also evaluated. The treatments of the patients were conducted according to the "COVID-19 (2019-nCoV Infection) Guide", which was prepared by the Ministry of Health for COVID-19 in Turkey (5).

\section{Data Collection}

The demographic variables and laboratory parameters of the patients, which included real-time reverse transcription-polymerase chain reaction (RT-PCR), C-reactive protein (CRP), D-dimer, Lymphocyte count: Lymphocyte (\%), Fibrinogen (mg/dl), arterial blood gas values taken at room air $\left(\mathrm{Ph}, \mathrm{PaCO}_{2}, \mathrm{HCO}_{3}, \mathrm{PaO}_{2}\right.$, $\left.\mathrm{SaO}_{2}\right)$ and ferritin $(\mathrm{ng} / \mathrm{ml})$ values were obtained before the treatment processes from the digital archive system in the hospital. The patients were divided as $\mathrm{SaO}_{2}$ $<93 \%$ and $\geq 93 \%$ to determine the mild and severe disease according to Ministry of Health for COVID-19 (2019-nCoV Infection) Guide. The PA chest radiography and thorax CT findings, which were recorded at the time of application of the patients, were also taken into consideration in the study. The mean period between PCR results time and CT images are maximally 24 hours in our hospital. The end-point of our study was the presence of at least one of the following results: (1) death from any cause in hospital (in the intensive care unit or clinic), (2) need for intensive care unit (ICU) transfer, (3) discharge. 


\section{Arterial Blood Gas Analyses}

The samples for arterial blood gas measurements of the COVID-19 patients were taken at rest, in a sitting position, and room air at room temperature. Then the samples were evaluated via a blood gas analysis device (Rapid lab 348. Biobak., Chiron, Bayer Diagnostic, UK).

\section{Laboratory Analyses}

Real-time reverse transcription-polymerase chain reactions (RT-PCR) were evaluated via throat swab specimens of all the patients in the study. The methods for RT-PCR in previous studies were adopted in the practice (6).

Complete blood cell counts were analyzed via a high-volume hematology analyzer (ADVIA 2120i, Siemens Healthcare Diagnostics Inc., Tarrytown, NY, USA). The blood samples were collected in potassium-ethylenediaminetetraacetic acid tubes and analyzed within one hour after venipuncture. CRP levels were determined via a nephelometric analyzer (BN II System, Siemens Healthcare Diagnostics Inc., Tarrytown, NY, USA) by the immunonephelometry method. Thus, the complete blood cell count and CRP findings of the patients were included in the evaluation.

\section{CT Protocols and Imaging Analyses}

High-resolution CT (HRCT) or chest CT scans were evaluated while screening for pulmonary lesions. All images were obtained via a 256-slice CT device (RevolutionTM CT; General Electric Healthcare Company, Chicago, Illinois, USA) with patients at the end of inspiration and in the supine position. The axial images were obtained craniocaudally and included the body parts from the thoracic inlet to the diaphragm. No contrast media was used during the scans. The scans were performed with the following technical parameters: HRCT and chest CT: $120 \mathrm{kV}$, $250 \mathrm{~mA}, 0.625$ slice thickness, $512 \times 512$ matrix. The reconstructed images were also obtained and used in the current study. Chest radiology specialist (Aydin AM, who had 23 years of experience in the profession) reviewed the chest CT images. Chest CT images were evaluated with both mediastinal (width: 350 $\mathrm{HU}$, level: $40 \mathrm{HU}$ ) and lung (width: $1400 \mathrm{HU}$, level: $-500 \mathrm{HU}$ ) window level settings.

In the study, we especially evaluated the two most common imaging features that were defined in previous studies. These included ground-glass opacities
(GGO) and consolidation $(7,8)$. The presence of a single lobe lesion was considered as limited involvement while multiple lobe lesions were considered as diffuse involvement for both GGO and consolidation.

\section{Statistical Analyses}

In the current study, IBM SPSS Statistics 21 (Statistical Product and Service Solutions version 21.0, authorization code: d91314f638c364094170; Armonk, NY, USA) Package software was used for the statistical analyses. The results were presented as mean \pm standard deviation. The level of statistical significance was regarded as $p<0.05$. Pairwise group variables were compared by using the Mann-Whitney $U$ test because the data in our study did not demonstrate a normal distribution. On the other hand, categorical variables were compared by using chi-square test. In binary logistic regression analysis, the calculations of the odds ratios (ORs) and the 95\% confidence interval values for adverse results concerning the potential risk factors were taken into account.

\section{RESULTS}

In the study, 200 patients with COVID-19 infections were included. Of these patients, 124 were males $(62 \%)$ while 76 were females $(38 \%)$. Mean ages of the male and female patients were $52.17 \pm 18.46$ and $50.76 \pm 20.65$, respectively. It was determined that 178 patients $(89 \%)$ were discharged (directly from clinic) while 17 patients (8.5\%) were transferred to ICU, in addition to five patients who died $(2.5 \%)$ (Figure 1). Mortality rate of the patients transferred to the ICU was $19.04 \%$ (4 of 21 patients). There was no significant difference in sex between the discharged, dead and transferred to ICU patients $\left(\mathrm{X}^{2}: 0.585, \mathrm{p}>\right.$ $0.05)$. There was no significant difference in age between discharged patients and patients who died and between transferred to ICU and died patients, but mean age was statistically higher in transferred to ICU patients than discharged patients $(p<0.05)$. Demographic characteristics and laboratory parameters of COVID-19 patients who died, transferred to ICU and discharged is shown in Table 1. PA chest radiography scans were performed in all patients, and only 7 patients $(3.5 \%)$ had abnormal features in the PA chest radiography images (GGO and/or peripheral consolidations). Furthermore, it was determined that 50 patients $(25 \%)$ had normal thorax CT findings and 139 patients (69.5\%) had abnormal thorax $\mathrm{CT}$ findings in addition to 11 patients who did not have any thorax CT scans (5.5\%). 


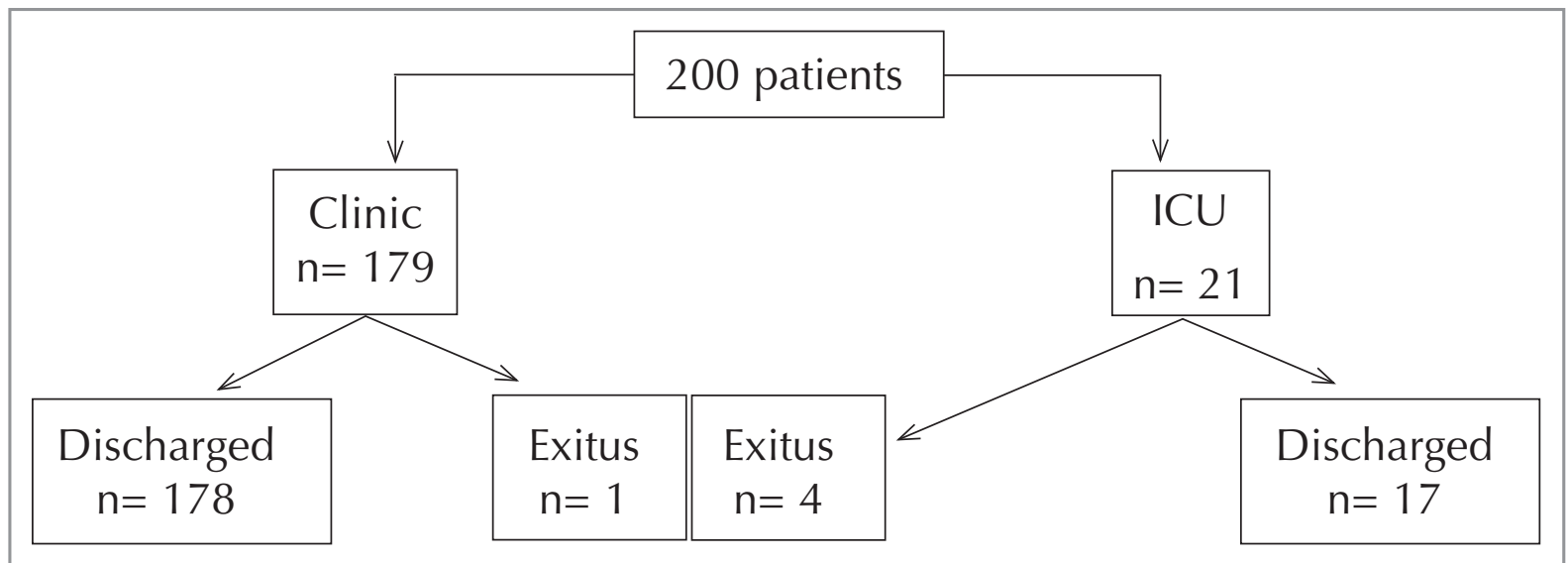

Figure 1. Flowchart of COVID-19 patient who discharged, transferred to ICU and exitus.

Table 1. Demographic characteristics and laboratory parameters in COVID-19 patients who died, transferred to ICU and discharged

\begin{tabular}{|c|c|c|c|}
\hline & $\begin{array}{c}\text { Discharged } \\
n=178\end{array}$ & $\begin{array}{c}\text { Death } \\
n=5\end{array}$ & $\begin{array}{c}\text { Transfer to ICU } \\
n=17\end{array}$ \\
\hline Sex (Male/female) & $109 / 69$ & $3 / 2$ & $12 / 5$ \\
\hline Age (Year) & $50.61 \pm 18.97^{\mathrm{a}}$ & $52.4 \pm 22.19$ & $62.12 \pm 19.83$ \\
\hline $\mathrm{CRP}(\mathrm{mg} / \mathrm{L})$ & $37.92 \pm 48.64^{b}$ & $88.02 \pm 57.71$ & $81.45 \pm 69.22$ \\
\hline Ferritin $(\mathrm{ng} / \mathrm{ml})$ & $228.34 \pm 249.99^{b, f}$ & $778.94 \pm 564.62$ & $638.61 \pm 641.41$ \\
\hline Fibrinogen & $365.67 \pm 146.91^{c, d, e}$ & $744.8 \pm 100.43$ & $514.64 \pm 205.57$ \\
\hline Lymphocyte (\%) & $21.64 \pm 11.61$ & $27.02 \pm 19.99$ & $19.13 \pm 10.7$ \\
\hline Neutrophil (\%) & $66.95 \pm 13.92$ & $61.28 \pm 20.19$ & $70.17 \pm 13.71$ \\
\hline Platelet $\left(10^{3} / \mu \mathrm{l}\right)$ & $203.1 \pm 65.28$ & $272.2 \pm 142.38$ & $226.88 \pm 87.03$ \\
\hline WBC $\left(10^{3} / \mathrm{ml}\right)$ & $6.68 \pm 3.11$ & $5.59 \pm 3.62$ & $7.37 \pm 3.72$ \\
\hline D-dimer (mg/L) & $1.69 \pm 1.67^{b}$ & $1.07 \pm 1.38$ & $1.45 \pm 2.21$ \\
\hline Troponin & $0.02 \pm 0.1^{\mathrm{b}}$ & $0.03 \pm 0.05$ & $0.64 \pm 1.77$ \\
\hline Procalcitonin (mg/L) & $1.67 \pm 0.74^{b}$ & $1.4 \pm 0.54$ & $1.18 \pm 0.6$ \\
\hline
\end{tabular}

In the evaluations, when the patients with $\mathrm{SaO}_{2}$ $\geq 93 \% \quad(n=131,65.5 \%)$ were compared with the patients with $\mathrm{SaO}_{2}<93 \%$ ( $n=69,34.5 \%$ ), no statistically significant difference was observed in terms of the presence and absence of lesions on PA radiography. On the other hand, there were abnormal thorax CT findings in 62 patients with $\mathrm{SaO}_{2}<93 \%(89.9 \%)$ while only 5 patients with $\mathrm{SaO}_{2}<93 \%(7.2 \%)$ had normal thorax CT findings (Table 2).

The ratios of patients who died and the patients who were transferred to the ICU with abnormal thorax CT findings were significantly higher compared to patients with normal thorax CT findings ( $p<0.05)$ (Table 3).
The GGO ratio in thorax CT was $60.4 \%(n=84)$ while the ratio of consolidation was $7.9 \%(n=11)$. Additionally, the ratio of GGO + consolidation was $31.7 \%(n=44)$. Accordingly, GGOs were mostly observed as multiple lobe involvements (44.5\%) and then, as lower lobe involvements (28.1\%). Furthermore, consolidations were mostly observed as multiple lobe involvements $(58.2 \%)$ and then, as upper lobe involvements (29.1\%). Accordingly, it was demonstrated that the types of lesions did not affect the ratios of mortality and ICU transfer (Table 4). However, limited or diffused lesions affected the results in patients with GGOs. The ratios of mortality 
Table 2. Presence and absence of lesions in PA chest radiography and Thorax CT scans in patients with $\mathrm{SaO}_{2} \geq 93 \%$ and $\mathrm{SaO}_{2}$ $<93 \%$

\begin{tabular}{|c|c|c|c|c|}
\hline PA chest radiography & & Normal & Abnormal & Total \\
\hline $\mathrm{SaO}_{2} \geq 93 \%$ & & $127(96.9 \%)$ & $4(3.1 \%)$ & $131(100 \%)$ \\
\hline $\mathrm{SaO}_{2}<93 \%$ & & $66(95.7 \%)$ & $3(4.3 \%)$ & $69(100 \%)$ \\
\hline Thorax CT & No thorax CT & Normal & Abnormal & \\
\hline $\mathrm{SaO}_{2} \geq 93 \%$ & $9(6.9 \%)$ & $45(34.4 \%)$ & $77(58.8 \%)$ & $131(100 \%)$ \\
\hline $\mathrm{SaO}_{2}<93 \%$ & $2(2.9 \%)$ & $5(7.2 \%)$ & $62(89.9 \%)$ & $69(100 \%)$ \\
\hline
\end{tabular}

Table 3. The ratios of patients who died and the patients who were transferred to the ICU according to the presence of lesions in Thorax CT

\begin{tabular}{|lcccc|}
\hline Thorax CT & Discharged & Death & Transfer to ICU & Total \\
\hline Normal & $50(100 \%)$ & 0 & 0 & $50(100 \%)$ \\
Abnormal & $117(84.2 \%)$ & $5(3.6 \%)$ & $17(12.2 \%)$ & $139(100 \%)$ \\
\hline$X^{2}: 8.956, p<0.05$ & & & \\
\hline
\end{tabular}

Table 4. The types of lesions on thorax CT scans according to the results

\begin{tabular}{|lcccc|} 
& GGO & Consolidation & GGO + Consolidation & Total \\
\hline Discharged & $70(58.9 \%)$ & $9(7.7 \%)$ & $38(32.5 \%)$ & $117(100 \%)$ \\
Death & $2(40 \%)$ & 0 & $3(60 \%)$ & $5(100 \%)$ \\
Transfer to ICU & $12(70.6 \%)$ & $2(11.8 \%)$ & $3(17.6 \%)$ & $17(100 \%)$ \\
\hline GGO: Ground-glass opacities, $X^{2}: 3.712, \mathrm{p}>0.05$ & & & \\
\hline
\end{tabular}

Table 5. The results of limited or diffused lesions in both GGOs and consolidations

\begin{tabular}{|c|c|c|c|c|}
\hline & Discharged & Death & Transfer to ICU & Total \\
\hline \multicolumn{5}{|l|}{ GGO } \\
\hline Limited & 66 (93\%) & $2(2.8 \%)$ & $3(4.2)$ & $71(100 \%)$ \\
\hline Diffuse & $42(73.7 \%)$ & $3(5.3 \%)$ & $12(21.1 \%)$ & $57(100 \%)$ \\
\hline \multicolumn{5}{|c|}{ Consolidation } \\
\hline Limited & $20(87 \%)$ & $1(4.3 \%)$ & $2(8.7 \%)$ & $32(100 \%)$ \\
\hline Diffuse & $27(84.4 \%)$ & $2(6.3 \%)$ & $3(9.4 \%)$ & $55(100 \%)$ \\
\hline
\end{tabular}

and transfer to the ICU in patients with diffused GGO were significantly higher compared to patients with limited GGOs (Table 5).

In logistic regression analysis, it was observed that $\mathrm{SaO}_{2}<93 \%(\mathrm{p}<0.05$, OR: 3.742, Cl: 1.016-13.788), CRP $>3.14 \mathrm{mg} / \mathrm{L} \quad(p<0.05$, OR: 1.156, Cl: 0.4592.907), neutrophils $\geq 77 \%(p<0.05$, OR: $0.207, \mathrm{Cl}$ : $0.062-0.691)$ and ferritin $\geq 300 \mathrm{ng} / \mathrm{ml}(\mathrm{p}<0.05, \mathrm{OR}$ : 6.055, Cl: 1.186-30.903) were independent predic- tors of the presences of abnormal findings in thorax CT (Table 6). Furthermore, it was discovered that troponin $\geq 0.06 \mu \mathrm{g} / \mathrm{L}(\mathrm{p}<0.05$, OR: 1.147, Cl: 0.021 1.041), platelet $<140(\mathrm{p}<0.01$, OR: 20.929, Cl: 2.833-154.585) and fibrinogen $\geq 350 \mathrm{mg} / \mathrm{dl}(\mathrm{p}<$ 0,001, OR: 52.158, Cl: 9.286-292.975) were independent predictors of the presences of diffused GGOs in thorax CT (Table 6). 
Table 6. Results of binary logistic regression analysis of potential predictors of the presence of abnormal findings and diffused GGOs in thorax CT

\begin{tabular}{|lcccc|}
\hline & The presence of abnormal findings in thorax CT & \multicolumn{2}{c|}{ The presence of diffused GGOs in thorax CT } \\
\hline & $\mathbf{p}$ & OR $(\mathbf{9 5} \% \mathbf{C I})$ & $\mathbf{p}$ & OR (95\% CI) \\
\hline Age $(\geq 40$ year) & 0.145 & $1.939(0.796-4.725)$ & 0.429 & $2.282(0.295-17.644)$ \\
Sex, male & 0.859 & $0.925(0.392-2.183)$ & 0.075 & $0.251(0.055-1.151)$ \\
Comorbidity & 0.937 & $1.042(0.369-2.944)$ & 0.423 & $0.539(0.119-2.437)$ \\
CRP $(>3.14 \mathrm{mg} / \mathrm{L})$ & $<0.05$ & $1.156(0.459-2.907)$ & 0.723 & $1.542(0.140-16.974)$ \\
Fibrinogen $(\geq 350 \mathrm{mg} / \mathrm{dl})$ & 0.780 & $1.156(0.459-2.907)$ & $<0.001$ & $52.158(9.286-292.975)$ \\
Ferritin $(\geq 300 \mathrm{ng} / \mathrm{ml})$ & $<0.05$ & $6.055(1.186-30.903)$ & 0.091 & $3.286(0.826-13.069)$ \\
WBC $\left(\geq 8.6 \times 10^{3} \mu \mathrm{l}\right)$ & 0.354 & $1.810(0.516-6.349)$ & 0.804 & $0.692(0.038-12.661)$ \\
Lymphocyte $(\geq 44 \%)$ & 0.435 & $0.723(0.320-1.632)$ & 0.143 & $2.656(0.718-9.830)$ \\
Neutrophils $(\geq 77 \%)$ & $<0.05$ & $0.207(0.062-0.691)$ & 0.910 & $1.157(0.091-14.735)$ \\
Platelet $\left(<140 \times 10^{3} \mu \mathrm{l}\right)$ & 0.106 & $3.284(0.776-13.902)$ & $<0.01$ & $20.929(2.833-154.585)$ \\
Troponin $(\geq 0.06 \mu \mathrm{g} / \mathrm{L})$ & 0.844 & $1.192(0.207-6.857)$ & $<0.05$ & $0.147(0.021-1.041)$ \\
SaO $(<93 \%)$ & $<0.05$ & $3.742(1.016-13.788)$ & $<0.05$ & $4.524(0.970-21.09)$ \\
\hline
\end{tabular}

\section{DISCUSSION}

The main findings of our retrospective study were that increased abnormal thorax $\mathrm{CT}$ ratios were observed in COVID-19 patients with $\mathrm{SaO}_{2}<93 \%$ although there was no statistically significant difference in terms of the presence and absence of lesions in PA radiography. Additionally, the ratios of mortality and transfer to the ICU were increased in patients with abnormal thorax CT findings. In thorax CT scans, GGO ratios were increased compared to consolidation ratios. Moreover, the ratios of mortality and transfer to the ICU in patients with diffused GGOs were significantly higher compared to patients with limited GGOs. Finally, decreased $\mathrm{SaO}_{2}$, increased CRP, and ferritin levels were discovered to be independent predictors of the presence of abnormal thorax CT findings. On the other hand, decreased platelet counts and increased troponin and fibrinogen levels were discovered to be independent predictors of the presence of diffused GGOs in thorax CT scans.

Early recognition of COVID-19 pneumonia is essential for the management of patients. The evaluation of clinical and laboratory findings along with imaging features can facilitate early diagnosis of COVID-19 pneumonia. Accordingly, PA radiography is often a first-line radiologic investigation for chest diseases. CXR can be used as a tool for identifying COVID-19 but it has been reported to be less sensitive especially in the early stage of the disease compared to
CT (9). In our study, thorax CT was used for the diagnosis and management of COVID-19 in the current pandemic situation just as in many countries. Within this framework, we observed that thorax CT could be more effective for diagnosing COVID-19 pneumonia especially in patients with $\mathrm{SaO}_{2}<93 \%$ despite normal PA radiographs. For this reason, we believe that thorax CT should be considered in patients with $\mathrm{SaO}_{2}<93 \%$.

Thorax CT is a method that can accurately assess the type and extent of lung lesions and the prevalence of thorax CT abnormalities in COVID-19 depends on the stage and severity of the disease. Moreover, the temporal evolution and extent of lung abnormalities are heterogeneous among different patients and dependent on the severity of the disease $(10,11)$. In this study, we observed increased abnormal thorax CT findings in COVID-19 patients who died and who were transferred to the ICU. In the comparison of discharged patients, the most common CT findings were GGOs while consolidations were significantly more frequent in severe/critical patients compared to ordinary groups in the study conducted by $\mathrm{Li}$ et al. (12). In the current study, no statistically significant difference was determined between the two groups although GGOs were the most common CT findings in terms of COVID-19 pneumonia. The reason for more frequent GGOs in patients who died or who were transferred to ICU could be that the thorax CT scans were taken at admission to the hospital. It was reported that GGO was the most common involve- 
ment in COVID-19 pneumonia, which was observed in approximately $98 \%$ of patients, and was usually observed in the early phases of the disease or mild pneumonia (13). Following the early phases of the disease, consolidation occurs at higher frequencies, which indicates that the disease is progressing rapidly. The results of our study demonstrated that the patients with GGOs, especially with diffused GGO, on thorax CT scans in early stages required monitoring and follow-ups more closely in terms of mortality. Furthermore, it was reported that multiple bilateral pulmonary lesions were observed more frequently among patients with unfavorable results $(11.1 \%)$ compared to patients with favorable results $(0.8 \%)$ (14). However, another study demonstrated that there was no difference in terms of the ratios of multilobar lesions in CT findings during preadmission between non-severe $(92.1 \%)$ and severe $(97 \%)$ patients with COVID-19. As stated in the limitations of this study, detailed information on CT findings was not provided (15). Generally, more extensive parenchymal impairment was associated with severe diseases in previous findings $(7,16,17)$.

Currently, the healthcare systems of countries are hanging by a thread due to the COVID-19 pandemic. Severe cases can be identified early by determining and standardizing parameters that can be analyzed easily and cheaply while predicting the severity of the disease. Early recognition of severe cases can improve the management and reduce the mortality rate of patients with COVID-19. In previous studies, several laboratory parameters were found as risk factors for mortality, such as higher troponin I, leukocytosis, neutrophilia, elevated procalcitonin, and ferritin in patients with COVID-19 $(14,18)$. Furthermore, in one meta-analysis, it was determined that especially CRP, PCT, IL-6, and ESR were positively correlated with the severity of COVID-19 (19). On the other hand, diffused distribution (rather than focal or multifocal) of thorax $\mathrm{CT}$ findings were associated with more severe disease $(7,16,20)$. Parenchymal involvement greater than $50 \%$ and interlobular septal thickening were correlated with ICU admission $(21,22)$. More extensive lung involvements were also correlated with lower $\mathrm{SpO}_{2}$ and elevated CRP, which may occur due to interstitial pulmonary edema or interstitial injury $(21,22)$. Interlobular septal thickening on CT was associated with ICU admission and longer stays in ICU (22). In a study conducted by Tan et al., it was reported that the CRP levels were posi- tively correlated with the CT severity scores $(R=0.62$, $p<0.01)$. Furthermore, the CRP level was found to be high in the early period before any changes in thorax CT scores were observed. In the study, the researchers stated that CRP could be used as a biomarker for assessing the severity of COVID-19 especially in developing countries (23). Infection-related biomarkers, such as neutrophil count, WBC, CRP, and procalcitonin levels, are elevated in the progressive stages of COVID-19. In this period, diffused GGOs with consolidation were observed in chest CT scans (24). In our study, we observed that increased troponin and fibrinogen levels, and low platelet levels were independent predictors of the presence of diffused GGOs in thorax CT scans. This may be interpreted that these parameters may be closely related with widespread radiological involvement. For this reason, we believe that the evaluation of laboratory findings that correlate with thorax $\mathrm{CT}$ findings can decrease the utilization rate of thorax CT.

This study had several limitations. Firstly, the study was conducted in a single healthcare center. Accordingly, our sample size was small and it adopted a retrospective design. The sample of the study only covered symptomatic patients who were admitted to the emergency department and pandemic clinic in our center. Frequently, CT scans that are performed early demonstrate few changes. For this reason, lower consolidation rates might be found in this study. Finally, the ratio of abnormal features in the PA chest radiography was low in our study. This may be due to the low sensitivity of the PA radiography, especially in the early stage of the disease, as well as the interpretation error of the PA radiography in our study. In addition, we saw higher d-dimer and lower lymphocyte levels in discharged patients. These laboratory parameters were obtained before the treatment and at the time of application. This finding was not evaluated since it was not primary aim of our study. Future studies will provide further information.

In conclusion, diffused GGOs on thorax CT are correlated with the rate of mortality and transfer to the ICU in patients with COVID-19. Furthermore, troponin, fibrinogen, and platelet levels can be used while predicting the distribution of diffusion in thorax CT scans. These laboratory parameters can be used while predicting extensive parenchymal disease on thorax CT scans. In future studies, larger sample sizes and participation from several healthcare centers can provide results that can be generalized further. 


\section{Acknowledgments}

Thanks to all the medical workers of our country as in the whole world for their effort against the COVID19. This study did not receive any financial support or funding.

Ethical Committee Approval: Ethical approval for this study was obtained from Firat University Ethical Committee (Decision No: 394781, Date: 04.06.2020).

\section{CONFLICT of INTEREST}

The authors have no relevant affiliations or financial involvement with any organization or entity with a financial interest in or financial conflict with the subject matter or materials discussed in the manuscript. This includes employment, consultancies, honoraria, stock ownership or options, expert testimony, grants or patents received or pending, or royalties

All authors read and approved the final manuscript.

\section{AUTHORSHIP CONTRIBUTIONS}

Concept/Design: FD, TT, MK, Ei

Analysis/Interpretation: FD, Ei

Data Acqusition: MK, AMA, ZAT

Writing: FD, MK

Clinical Revision: TT, El

Final Approval: All of authors

\section{REFERENCES}

1. Güneyli S, Atçeken Z, Doğan H, Altınmakas E, Atasoy KÇ. Radiological approach to COVID-19 pneumonia with an emphasis on chest CT. Diagn Interv Radiol 2020; 26(4): 323-32.

2. Li K, Fang Y, Li W, Pan C, Qin P, Zhong Y, et al. CT image visual quantitative evaluation and clinical classification of coronavirus disease (COVID-19). Eur Radiol 2020; 30(8): 4407-16.

3. Chung $M$, Bernheim A, Mei X, Zhang N, Huang M, Zeng $X$, et al. CT imaging features of 2019 novel coronavirus (2019-nCoV). Radiology 2020; 295(1): 202-7.

4. Li M, Lei P, Zeng B, Li Z, Yu P, Fan B, et al. Coronavirus disease (COVID-19): Spectrum of CT findings and temporal progression of the disease. Acad Radiol 2020; 27(5): 603-8.

5. T.C. Sağlık Bakanlığı Halk Sağlığı Genel Müdürlüğü. COVID-19 (SARS-CoV-2 Enfeksiyonu) Erişkin Hasta Tedavisi Rehberi. T.C. Sağlık Bakanlı̆̆ı, 7 Mayıs 2021, Ankara. Accessed date: 10 May 2021. Available from: https://covid19.saglik.gov.tr/Eklenti/40719/0/covid19rehberieriskinhastayonetimivetedavipdf.pdf
6. Huang C, Wang Y, Li X, Ren L, Zhao J, Hu Y, et al. Clinical features of patients infected with 2019 novel coronavirus in Wuhan, China. Lancet 2020; 395(10223): 497-506.

7. hao W, Zhong Z, Xie X, Yu Q, Liu J. Relation between chest $C T$ findings and clinical conditions of coronavirus disease (COVID-19) pneumonia: A multicenter study. AJR Am J Roentgenol 2020; 214(5): 1072-7.

8. Ajlan AM, Ahyad RA, Jamjoom LG, Alharthy A, Madani TA. Middle East respiratory syndrome coronavirus (MERSCoV) infection: Chest CT findings. AJR Am / Roentgenol 2014; 203(4): 782-7.

9. Wong HYF, Lam HYS, Fong AH, Leung ST, Chin TW, Lo CSY, et al. Frequency and distribution of chest radiographic findings in patients positive for COVID-19. Radiology 2020; 296(2): 72-8.

10. Pan $Y$, Guan $H$, Zhou S, Wang Y, Li Q, Zhu T, et al. Initial $C T$ findings and temporal changes in patients with the novel coronavirus pneumonia (2019-nCoV): A study of 63 patients in Wuhan, China. Eur Radiol 2020; 30(6): 33069.

11. Kwee TC, Kwee RM. Chest CT in COVID-19: What the Radiologist Needs to Know. Radiographics 2020; 40(7): 1848-65.

12. Li K, Wu J, Wu F, Guo D, Chen L, Fang Z, et al. The clinical and chest $C T$ features associated with severe and critical COVID-19 pneumonia. Invest Radiol 2020; 55(6): 327-31.

13. Liang $T$, Liu Z, Wu CC, Jin C, Zhao $H$, Wang $Y$, et al. Evolution of CT findings in patients with mild COVID-19 pneumonia. Eur Radiol 2020; 30(9): 4865-73.

14. Hu L, Chen S, Fu Y, Gao Z, Long H, Ren HW, et al. Risk factors associated with clinical outcomes in 323 coronavirus disease 2019 (COVID-19) hospitalized patients in Wuhan, China. Clin Infect Dis 2020; 71(16): 2089-98.

15. Li X, Xu S, Yu M, Wang K, Tao Y, Zhou Y, et al. Risk factors for severity and mortality in adult COVID-19 inpatients in Wuhan. J Allergy Clin Immunol 2020; 146(1): 110-8.

16. Yu M, Xu D, Lan L, Tu M, Liao R, Cai S, et al. Thin-section chest CT imaging of coronavirus disease 2019 pneumonia: comparison between patients with mild and severe disease. Radiol Cardiothoracic Imaging 2020; 2(2): 200126.

17. Lyu P, Liu X, Zhang R, Shi L, Gao J, et al. The performance of chest CT in evaluating the clinical severity of COVID-19 pneumonia: identifying critical cases based on CT characteristics. Invest Radiol 2020; 55(7): 412-21.

18. Rod JE, Oviedo-Trespalacios O, Cortes-Ramirez J. A briefreview of the risk factors for covid-19 severity. Rev Saude Publica 2020; 54: 60.

19. Zenga $F$, HuangC $Y$, Guoa $Y$, Yin $M$, Chen $X$, Xiao $L$, et al. Association of inflammatory markers with the severity of COVID-19: A meta-analysis. Int J Infect Dis 2020; 96: 46774. 
20. Tabatabaei SMH, Talari H, Moghaddas F, Rajebi $H$. Computed tomographic features and short-term prognosis of coronavirus disease 2019 (COVID-19) pneumonia: a single-center study from Kashan, Iran. Radiol Cardiothorac Imaging 2020; 2(2): e200130.

21. Yang $X, Y u Y, X u$ J, Shu $H, X i a$ J, Liu $H$, et al. Clinical course and outcomes of critically ill patients with SARS-CoV-2 pneumonia in Wuhan, China: a single-centered, retrospective, observational study. Lancet Respir Med 2020; 8(4): 475-81.

22. Barbosa CS, Chaves GWOG, Vilela de Oliveira C, Bachion GH, Chi CK, Cerri GG, et al. COVID-19 pneumonia in the emergency department: correlation of initial chest CT findings with short-term outcome. Emerg Radiol 2020; 27(6): 691-9.
23. Tan C, Huang Y, Shi F, Tan K, Ma Q, Chen Y, et al. $C$-reactive protein correlates with computed tomographic findings and predicts severe COVID-19 early. I Med Virol 2020; 92(7): 856-62.

24. Zhang B, Zhang J, Chen H, Chen L, Chen Q, Li M, et al. Novel coronavirus disease 2019 (COVID-19): relationship between chest CT scores and laboratory parameters. Eur J Nucl Med Mol Imaging 2020; 47(9): 2083-89. 